\title{
Kristina Giacometti
}

OŠ Nova Rača

kristinagiacometti@yahoo.com

\section{Od čudesnoga do fantastičnoga: dimenzije svjetova Ivane Brlić-Mažuranić i Nade Iveljić}

Izvorni znanstveni članak / original research paper

Primljeno / received 20. 5. 2013.

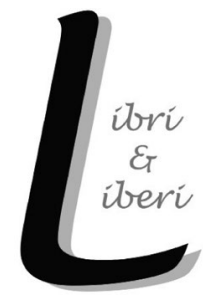

Služeći se inspirativnim polemikama o povezanosti bajke s bitno mlađim oblikom (fantastikom), uspoređuju se $i$ analiziraju Priče iz davnine Ivane Brlić-Mažuranić, koje se svrstavaju u umjetničke bajke, i moderne bajke ili fantastične priče Nade Iveljić iz zbirke Šestinski kišobran. Tipologija i karakter fikcionalnih svjetova dviju zbirki određuju se na temelju epistemoloških, ontoloških i strukturnih razlika između bajke i fantastike, dviju vrsta pripovijedi koje se u književnoznanstvenoj literaturi obično uspoređuju, a katkada i poistovjećuju. U osloncu na dosadašnje teorijske spoznaje, provodi se književnoteorijska analiza te se pokazuje da se svjetovi iz zbirke Šestinski kišobran $u$ ontološkim, epistemološkim i strukturnim dimenzijama udaljavaju od bajke kakvu piše Ivana Brlić-Mažuranić i evoluiraju u fantastičnu priču.

Ključne riječi: bajka, fantastična priča, epistemološke razlike, ontološke razlike, ontološke sličnosti, strukturne razlike

\section{Uvod: od bajke do fantastične priče}

Bajkama nazivamo priče o čudesnim događajima u kojima se glavni junak svojom hrabrošću i mudrošću suprotstavlja silama zla. Uz njih se vežu termini ‘čudesan' i ‘čudesnost', a čuda koja se događaju nikoga ne iznenađuju i ne užasavaju sudionike zbivanja. Ona se događaju kao nešto normalno. „Čudesno nije odlika odnosa prema ispričanim događajima, već svojstvo same prirode tih događaja. [...] U stvari, bajka je samo verzija čudesnoga, i natprirodna zbivanja u njoj ne izazivaju nikakvo iznenađenje“ (Todorov 1987: 58). Ime ove 'utjeloviteljice' čudesnoga 
potječe od glagola bajati, a to ,prvobitno znači čarati, vračati, govorenjem posebnih riječi i obavljanjem posebnih radnji tjerati od koga ili navlačiti na koga bolest ili kakvo zlo“ (Anić 2003: 51). Bajka je svojom čudesnošću i arhetipskim jezikom oduvijek budila zanimanje znanstvenika, a prije nego li je drukčije određena, smatrana je „vrstom priče koju su ustanovila braća Grimm“ (Jolles 2000: 203). Ova je književna vrsta prošla svoj razvojni put. Tako postoje brojne podjele bajki, a nazivi nisu usuglašeni. Pojedini nazivi kategorija su: narodna ili usmena i umjetnička bajka (Crnković 1987: 9); klasična i moderna bajka (Pintarić 2008: 10-11) i narodna i nenarodna bajka (Hameršak 2010: 115). U nastavku ovoga rada koristit ćemo se nazivima narodna i umjetnička bajka jer su se ti termini s vremenom uvriježili u teorijskoj literaturi. ${ }^{1}$

Iz narodne se bajke razvila umjetnička bajka, a iz nje naposljetku fantastika, koju karakterizira 'fantastično'. Navedeni termin potječe od grčke riječi fantastikos, što bi značilo biti sposoban predočavati, tvoriti slike: „Fantastika je ono što je stvoreno maštom, a fantastičan je onaj koji je izvan realnosti“ (Anić 2003: 147). Glagol 'fantazirati' također je blizak prethodno spomenutim terminima (iako u svakodnevnome govoru često ima pejorativno značenje), a njegovo je značenje rječnikom definirano kao „zamišljati ili pričati o nečemu bez oslonca u stvarnosti“ (ibid.). Problematika fantastične pripovijedi i prirode fantastičnoga predstavlja veliku 'petlju' dijela teorije književnosti, pa se kroz povijest mnogo polemiziralo smatra li se fantastiku žanrom ili samo svojstvom književnih tekstova. Ako se priklonimo teoriji da je fantastika žanr, onda je riječ o uskoj definiciji u koju se ne mogu ubrojiti neki postmoderni tekstovi koje bismo već na prvi pogled nazvali fantastičnima, no ako ju shvatimo kao svojstvo, tada je riječ o prevelikom broju žanrovski heterogenih tekstova. Jurica Pavičić u svojem članku „Neka pitanja fantastične književnosti“ upozorava da se ne možemo u potpunosti prikloniti niti jednoj teoriji jer „se one teoretičare koji shvaćaju fantastiku kao svojstvo najčešće kritizira kao previše izdašne u korištenju tog termina, a one koji su skloni fantastiku promatrati kao žanr kritizira se kao previše isključive“" (1996: 135).

U nastavku ovoga rada fantastičnu književnost smatrat ćemo skupinom književnih žanrova, ${ }^{2}$ za koju će se koristiti jednostavniji naziv fantastika. Fantastika je prošla kroz filogenetski razvoj te se afirmirala u skupinu zasebnih žanrova, a jednim od njih smatrat će se i fantastična priča. Pojam „fantastična priča“, kojim

${ }^{1}$ Primjerice, Dubravka Težak u svojem djelu Hrvatska poratna dječja priča (1991: 7) govori o narodnoj i umjetničkoj bajci. Potom u suautorstvu sa Stjepkom Težakom objavljuje djelo Interpretacija bajke (1997: 18; 50), gdje na isti način govori o narodnoj i umjetničkoj bajci. Milivoj Solar u svojem Rječniku književnog nazivlja (2006: 33-34), prilikom definiranja bajke, također koristi Crnkovićeve nazive.

2 Ovakvo rješenje donosi Darko Suvin u eseju „Promišljanja o smislu 'fantastike' ili fantastične proze“" (2001). 
ćemo se ovdje koristiti, ne bi trebalo poistovjetiti s pojmom „fantastična priča“ kojim se neki književni teoretičari koriste pri imenovanju fantastične književnosti (Crnković 1987: 9, Pintarić 2008: 11, Težak 1991: 11). Zbog istovremene bliskosti priča Nade Iveljić s narodnom bajkom i fantastikom, kao sinonim za fantastičnu priču u ovome će se radu upotrebljavati i pojam „moderna bajka“. Ovaj je pojam također potrebno razlikovati od naziva „moderna bajka“ kojim se koristi Ana Pintarić (2008: 11). ${ }^{3}$

Iako se često govori o velikoj sličnosti čudesnoga svijeta bajki i onoga fantastike, namjera je ovoga rada proučiti odraz strukturnih, epistemoloških i ontoloških razlika između bajke i fantastike u zbirkama Priče iz davnine Ivane Brlić-Mažuranić (1916) i Šestinski kišobran Nade Iveljić (1972). Do sada se nitko nije pomnije osvrnuo na ova djela navedenih autorica u naznačenom kontekstu. Pritom će se u obzir uzeti i činjenica da je matricu bajke do određene mjere moguće prepoznati u svakom tekstu koji pripada fantastici te da se bajka i fantastika utoliko međusobno prožimaju pa ih je bespredmetno sasvim razdvajati.

\section{Definiranje posebnoga odnosa prema stvarnosti u bajci i fantastici: složena povezanost dviju vrsta}

Iako je fantastika moderna skupina žanrova koja je evoluirala iz bajke, fantastiku i bajku često se poistovjećuje, a o njihovoj sličnosti svjedoči i tipologija fantastike koju donosi kritičar Dieter Petzold u članku „Fantastic, Fiction and Related Genres“ (1986).

Kako bi se Petzoldovo određenje fantastike pravilno razumjelo, potrebno je podrobno analizirati pojam fikcionalnoga svijeta. Fikcionalni svjetovi mogu se usporediti sa svijetom u kojemu živi čitatelj, no ne bi trebalo miješati usporedbu i poistovjećenje jer, ,izmišljeni svijet nije zbiljski nego pretpostavljen“(Peleš 1999: 15). Sukladno tomu, u nastavku će se fikcionalni svjetovi promatrati kao entiteti oprečni izvornoj stvarnosti, odnosno svijetu u kojemu živi čitatelj. Fikcionalne svjetove podijelit ćemo na fantastične fikcionalne svjetove i realistične fikcionalne svjetove. Za fantastične fikcionalne svjetove koristit ćemo Tolkienov naziv sekundarni svijet, ${ }^{4}$ a takve svjetove treba shvatiti kao autonomne strukture koje, uz realistične, sadrže i veliki broj fantastičnih elemenata. Realistične fikcionalne svjetove nazivat ćemo primarnim svjetovima te pritom pod primarnim svijetom podrazumijevati fikcionalni svijet koji ne sadrži fantastične elemente, odnosno u

3 Pintarić se pojmom moderne bajke koristi za imenovanje bajki koje se u ovome radu nazivaju umjetničkim bajkama.

4 Pojam sekundarnoga svijeta prvi spominje J. R. R. Tolkien, u predavanju „On Fairy Tales“ iz 1939. (1966). 
kojemu se događaji odvijaju u skladu sa zakonima fizike kakvu poznajemo. Iako su i primarni i sekundarni svjetovi ponekad slični izvornoj stvarnosti, to neće utjecati na njihov status, odnosno bez obzira na sličnost s izvornom stvarnošću, primarni i sekundarni svjetovi ne mogu biti manje ili više fikcionalni.

Spominjući svjetove (u ovom slučaju to su svijet izvorne stvarnosti, fantastični fikcionalni svijet i realistični fikcionalni svijet) i njihove odnose, zagazili smo u područje ontologije, ${ }^{5}$ znanosti koja je iz filozofije i logike interpolirana u književnost. Rasprave o prostoru i vremenu, odnosno temama kao što su: što je to svijet, kakvi sve svjetovi postoje, kako su konstituirani, kakvi su njihovi odnosi, po čemu se razlikuju i što se događa kada se naruše granice među njima - postale su temom ontološkoga pristupa književnosti. Ako usporedimo fikcionalne svjetove sa svijetom izvorne stvarnosti, jasno je da se oni uvelike razlikuju po ontološkom statusu. S obzirom da se ontološki status svijeta odnosi na pitanje načina postojanja, odnosno na status koji svijet ima s obzirom na izvornu stvarnost, fantastične fikcionalne svjetove bajke i fantastike usporedit ćemo s obzirom na način kojim se odnose prema izvornoj stvarnosti.

Petzold (1986: 16) za fantastični fikcionalni svijet, ,u kojemu se čudesno prikazuje kao normalno, a da pritom ne izaziva ni iznenađenje niti čuđenje ni kod likova u priči niti kod samoga pripovjedača“, također koristi naziv sekundarni svijet, a svoju tipologiju fantastike temelji na različitom odnošenju sekundarnoga svijeta teksta prema izvornoj stvarnosti. Ove odnose objasnit ćemo u osloncu na Petzoldova četiri načina kojima se fantazmatski tekstovi odnose prema stvarnosti, a to su: subverzivni, alternativni, deziderativni i aplikativni način (17).

U subverzivnom je načinu sekundarni svijet oblikovan tako da dovodi u pitanje čitateljevo shvaćanje stvarnosti, odnosno takav se svijet doima normalnim ili realističnim sve dok njegovu mirnu površinu ne zamuti neki neobičan ili neobjašnjiv događaj. Petzold u nastavku ističe da su tipični žanrovi u kojima prevladava subverzivni odnos prema stvarnosti gotička i jeziva priča (ibid.).

Alternativni način zapravo prikazuje drukčiji način odnošenja prema izvornoj stvarnosti, u kojoj su sekundarni svjetovi prikazani kao alternativa mogućoj zbilji. Izvedeni su racionalnom mentalnom aktivnošću kao što je analiza i izvođenje, a u idealnom slučaju bez kršenja prihvaćenih prirodnih zakona. Tipični žanrovi u kojima prevladava alternativni odnos prema stvarnosti jesu znanstvena fantastika i utopijska književnost (ibid.).

Tekstovi koji se na deziderativan način odnose prema stvarnosti izražavaju ljudske želje te kao da govore čitatelju da je taj (sekundarni) svijet bolji od našega,

Riječ ontologija dolazi od grčke riječi ón što znači biće i logos što znači znanost. Ontologija je prvo spomenuta u Aristotelovom djelu Metafizika te se o njoj govori kao o prvoj filozofiji. Godine 1656. Johannes Clauberg je naziva ontosophiom te je to bio početak ontologije (Cipra 2003: 13). 
nama poznatoga svijeta. Žanrovi u kojima prevladava deziderativni način odnošenja prema stvarnosti su ljubavni i pustolovni romani. Iako je element ispunjenja želja značajan i za bajku i za fantastičnu priču, one mogu izražavati mnogo dublje, elementarnije želje, kao što su žudnja za vječitom mladošću, snagom i moći (ibid.).

Valja još spomenuti aplikativni način koji podrazumijeva paralelizam sekundarnoga svijeta i izvorne stvarnosti. Sekundarni svjetovi, koji izgledaju drukčije od izvorne stvarnosti, supostoje s izvornom stvarnošću i međusobno se ne dokidaju. Petzold tu svrstava djela visoke razine apstrakcije (kao što je to primjerice Tolkienov Gospodar prstenova), ali ovdje se mogu svrstati i tipične bajke (ibid.).

Iz navedenoga prozlazi da se, prema Petzoldu, sekundarni svjetovi bajke i fantastike na isti način (aplikativni) odnose prema izvornoj stvarnosti. Međutim, u slučaju bajke ne možemo govoriti o ontološkom dvojstvu (dakle, ona nema primarni i sekundarni svijet, nego samo sekundarni). U nastavku ćemo stoga dubljom analizom usporediti sekundarni svijet bajke i sekundarni svijet fantastike te govoriti o njihovim ontološkim razlikama.

Također, budući da se bajka i fantastika, osim na ontološkoj razini, međusobno razlikuju i na epistemološkoj i strukturnoj razini, u sljedećem ćemo odjeljku pristupiti analizi svih tih razlika, od jednostavnijih ka složenijima.

\section{Strukturne, epistemološke i ontološke razlike bajke i fantastike}

Pri razmatranju razlika između bajke i fantastike valja naglasiti da se „ključna razlika svodi na to da je [bajka] zbog svoje izvorno govorne tradicije vezana uz razmjerno krute konvencije o duljini, građi, likovima, mjestu [i vremenu] zbivanja, a [fantastika je] nezavisnija od tih ograničenja“ (Petzold 1986: 17). Ako u opseg razlika ubrojimo i pitanje vjerodostojnosti napisanoga, odnosno nevjerodostojnost bajke nasuprot pouzdanosti fantastike, onda možemo govoriti o razlikama između fantastične priče i narodne bajke na trima razinama: strukturnoj (duljina i građa priče), epistemološkoj (pitanje pouzdanosti) i ontološkoj (građa i međusobni odnosi fikcionalnih svjetova) ${ }^{6}$

Narodna bajka je prema Dubravki Težak određena kratkoćom te strogom i lako prepoznatljivom strukturom priče, primjerice: 1. kraljevićev odlazak u svijet, 2. kraljević susreće stvarne i fantastične likove koje svrstavamo u dobre ili zle, 3. kraljević čini niz junačkih djela i bori se protiv zlih likova, 4. kraljević se vraća kući

${ }_{6}$ Slične razlike između bajke i fantastike spominje Maria Nikolajeva u članku „Fairy tale and Fantasy: From Arhaic to Postmodern“ (2003). Ona stavlja bajku i fantastiku u suodnos te spominje razlike u strukturi (ali pritom podrazumijeva kronotop, odnosno za nju je strukturna razlika u jednodimenzionalnosti svijeta bajke naspram dvodimenzionalnosti ili višedimenzionalnosti svijeta fantastike), genološke te epistemološke razlike. 
s nagradom za svoja djela te priča ima sretan završetak. Uz ovakvu kompoziciju djela, Dubravka Težak ističe da narodnu bajku karakteriziraju stereotipni početak (Jednom davno bijaše...) i završetak (Živjeli su sretno do smrti). Nadalje, karakterističan leksik, struktura rečenice i stilska izražajna sredstva specifičan su način izražavanja koji priziva drevnu usmenu tradiciju (1997: 21). Jolles također govori o jeziku bajke, odnosno spominje ,jezičnu gestu bajke“ koja ,istupa toliko snažno pa se zbivanje u njoj uređuje na tako određen način da ju se htjelo promatrati kao pravi sadržaj bajke“ (2000: 227).

Od ovako strukturirane bajke fantastika često preuzima stereotipnu kompoziciju priče, ali ju, ovisno o tematici, manje ili više prilagođava sebi. Budući da razmatranje fantastike koja strukturu zapleta bajke gotovo u potpunosti mijenja nadilazi djelokrug ovoga rada, u nastavku je navedena struktura na koju se često nailazi u fantastici, a u kojoj postoji najmanje izmjena i prilagodbi, odnosno, koja je najsličnija bajci: (1) junak (koji je najčešće dijete siroče nesvjesno svojega podrijetla) odlazi od kuće, (2) susreće nove likove (stvarne i fantastične) od kojih će mu neki postati pomagači, neki protivnici, a neki će se kolebati između strane dobra i strane zla, (3) junak kreće u potragu, slijedi (4) bitka dobra i zla, na kraju (5) heroj se vraća kući sa spoznajom o svojem podrijetlu te je potraga završena. Za ovakvu fantastiku još uvijek nije ustaljen termin, ${ }^{7}$ ali tako strukturirana priča ima realan završetak koji ne mora nužno biti sretan. Iako ponešto izmijenjena, struktura fantastike svojim izgledom podsjeća na strukturu bajke, no ono što razlikuje bajku od fantastike, konačna je namjera. Bajka je opterećena didaktikom i njezin je zadatak prenijeti sadržaje narodne mudrosti i generacijskoga pamćenja na nove generacije, dok je uloga fantastike ispričati priču na najkvalitetniji mogući način.

Jolles drži da su u bajci mjesto i vrijeme neodređeni jer ,čim bajka stekne povijesna obilježja, gubi nešto od svoje snage“ (2000: 226). Isto vrijedi i za likove u bajci koji također moraju ,imati onu neodređenu sigurnost na kojoj se razmrskava nemoralna stvarnost“" (ibid.). U vezu s Jollesovim može se dovesti i tumačenje Kurta Rankea, koji bajku vidi kao „priču čudesnoga sadržaja, sa svojim kategorijama vremena, prostora i uzroka, koja ne teži vjerodostojnosti““ (1978: 2). S obzirom na to da bajka nikada nije povijesno i vremenski određena, jer bi time izgubila svoju bajkovitu vrijednost, proizlazi da je nastala iz priče o nečemu neistinitome, nevjerodostojnome ili nestvarnome. Upravo na pitanju ispitivanja vjerodostojnosti

Farah Mendleshon rabi termin fantastika potrage (2008: 1), dok John Clute i John Grant u Enciklopediji fantastike objašnjavaju da termin pustolovna fantastika zapravo obuhvaća herojsku fantastiku i fantastiku mača i magije, ali termin još nije ušao u široku uporabu (1997: 915-916). 
bajke zasniva se njezina epistemološka ${ }^{8}$ vrijednost. Interpoliranjem epistemologije $\mathrm{u}$ istraživanje književnosti počelo se raspravljati o pitanjima: kako tumačiti svijet čiji smo dio, što o tom svijetu treba znati, postoji li netko tko to zna te kakvo je to znanje i koliko je pouzdano.

Zbog svojega formulnoga početka: Jednom davno bijaše..., bajka u svojoj biti ne zahtijeva da joj se vjeruje, a u fantastici je obrnuta situacija. Ona počinje bez stereotipnoga početka, a radnja se najčešće smješta u dobro razvedene svjetove koji čitatelja uvjeravaju u svoju istinitost i vjerodostojnost. Unatoč tomu, u fantastici čitatelj prihvaća opisane događaje kao 'stvarne' u okviru fikcionalnoga svijeta, odnosno prihvaća 'fantastično' kao normalan dio svijeta koji je autor stvorio. Osim toga, $\mathrm{u}$ fantastici postoji i mogućnost shvaćanja fantastičnih događaja na racionalan način, odnosno mogućnost objašnjenja fantastičnih događaja, na kraju priče, kao junakovih snova ili halucinacija (Nikolajeva 2003: 150).

$\mathrm{S}$ obzirom da je pretpostavljen, fikcionalni svijet stvaran je onoliko koliko su mu sastavnice dobro povezane. Sastavnice fikcionalnih svjetova čine prostorvrijeme i likovi, a o tome govori Mihail Bahtin u esejima „Oblici vremena i kronotopa u romanu“ iz 1937. i „Ep i roman“ iz 1941. ${ }^{9}$ Bahtin navodi da su prostor i vrijeme međusobno povezani te ih treba shvatiti kao jedinstveni entitet koji naziva kronotopom (prostor-vrijeme). Bahtin dalje raspravlja o likovima te navodi da kronotop određuje i lik u djelu (1989: 84). U nastavku rada oslonit ćemo se na Bahtinove teorijske uvide te ćemo osnovnim sastavnicama književnih svjetova smatrati prostor-vrijeme i likove.

Radnja bajke odvija se u,jednodimenzionalnom fantastičnom svijetu“(Hranjec 2006: 22) u kojemu paralelno postoje i realistični i čudesni elementi te nema jasnih granica između spomenutih elemenata. Za takav fantastični svijet bajke takođerćemo upotrijebiti naziv 'sekundarni svijet'. No, za razliku od bajke, koja se odvija samo u sekundarnome svijetu, koji uključuje i primarni svijet stapajući ih u jedno, radnja fantastike obično je smještena u više svjetova koji postoje usporedno, a u najvećem se broju djela pojavljuju po jedan primarni i jedan sekundarni svijet. Ovaj sekundarni svijet ,sekundaran je u smislu da je samosvojan, cjelovit i smisleno ustrojen, ali i fantazmagoričan pa ga po nizu konstrukcijskih i sadržajnih osobitosti, uključujući njegovu 'genezu' razlikujemo od iskustvene stvarnosti“ (Kravar 2010: 36).

\footnotetext{
8 Riječ epistemologija dolazi od grčke riječi episteme što znači znanje i logos što znači znanost. To je grana filozofije koja se bavi prirodom i dosegom znanja, a još je Platon smatrao da je znanje istinito vjerovanje koje se može poduprijeti nekim obrazloženjem ili objašnjenjem (usp. Greco 2004: 1).

9 Ovi eseji su, zajedno s još nekim Bahtinovim radovima, objavljeni 1981. godine u engleskome prijevodu, u knjizi The Dialogic Imagination: Four Essays by M. M. Bakhtin i 1989. godine u srpskome prijevodu, u knjizi O romanu. Eseje citiramo prema potonjem izdanju.
} 
Vrijeme i mjesto zbivanja u bajci nije točno određeno, što znači da možemo govoriti o bezvremenosti i besprostornosti, a u fantastici to nije slučaj. Sekundarni je svijet najčešće visokoapstraktno razveden, nepostojeći svijet koji ima neko ime, dok primarni svijet čini povijesno i zemljopisno provjerljiv kronotop. Fikcionalni je svijet bajke uvijek jedan svijet u kojemu čudesno i realno supostoje i prožimaju se, dok fikcionalni svijet fantastike čini ontološko dvojstvo, odnosno najčešće su prisutni i primarni i sekundarni svijet između kojih su naglašene granice, a samo neki (odabrani) likovi mogu te granice slobodno prelaziti. Prilikom prelaska likova iz jednoga svijeta u drugi nastaje čuđenje, a to je također jedna od odlika fantastike: ,[1]ikovi iz [primarnoga] svijeta koji se susreću s drugim svijetom isprva su iznenađeni i šokirani, ali nakon početnog čuđenja prihvaćaju njegovo postojanje“ (Zima 1997: 46). Za razliku od likova u bajkama, koji su „lišeni plastičnosti i individualnih crta“" (Hranjec 2006: 22) te su karakterizirani crno-bijelom tehnikom, što znači da su ili izrazito zli ili izrazito dobri, u fantastici je i dobrim i zlim likovima dodana individualnost, a postoje i kolebljivci koji gledaju svoje interese te se katkada priklanjaju strani dobra, a katkada strani zla.

U nastavku ćemo, kao što je prethodno najavljeno, pristupiti analizi bajki iz zbirki Priče iz davnine i Šestinski kišobran te preko spomenutih strukturnih, epistemoloških i ontoloških razlika nastojati odrediti obilježja umjetničke bajke Ivane Brlić-Mažuranić, a potom je i razlučiti od fantastične priče odnosno moderne bajke kakvu piše Nada Iveljić.

\section{Fikcionalni svjetovi Ivane Brlić-Mažuranić i Nade Iveljić}

Iz narodne se bajke razvila umjetnička bajka, tvorevina ,[koja] obuhvaća vrlo široko područje" (Crnković 1987: 11), ali je ipak moguće povući razlikovnu crtu između narodne i umjetničke bajke. Najčešće je riječ o pričama koje sadrže uočljive strukturne razlike s obzirom na narodnu bajku. U umjetničkoj bajci većinom izostaju stereotipni uvod i završetak, ali se zbog bajkovitoga načina pripovijedanja često osjeća duh narodne bajke. Ana Pintarić u djelu Umjetničke bajke: teorija, pregled $i$ interpretacija navodi da je umjetničku bajku u svjetskoj književnosti razradio H. C. Andersen te da je Ivana Brlić-Mažuranić jedna od predstavnica hrvatske umjetničke bajke (2008: 10).

Priče iz davnine (1916) zbirka je od osam bajki ${ }^{10} \mathrm{u}$ kojima se pojavljuju likovi

${ }^{10}$ Priče iz davnine govore o čarobnjaku Striboru i snahi-zmiji („Šuma Striborova“), divu Regoču iz Legena i vili Kosjenki s oblaka (,Regoč“), želji za velikim bogatstvom ribara Palunka („Ribar Palunko i njegova žena“), Potjehovoj potrazi za istinom te zlim bjesovima („Kako je Potjeh tražio istinu“), svijetu Kitež-planine, zlim vilama Zatočnicama te konačnoj pobjedi dobra nad zlim („Bratac Jaglenac i sestrica Rutvica“), djedu Neumijki i javorićima („Lutonjica Toporko i devet župančića“), Nevičici, kćerki mlinara i baki Mokoš („,Sunce djever i Neva Nevičica“) te o Jagoru, zloj maćehi i babi Poludnici (,Jagor“). 
iz slavenske mitologije i usmene književnosti (usp. Hranjec 2006: 60). Unatoč povezanosti s narodnom bajkom, ove se bajke od nje udaljavaju te ih je moguće dovesti u vezu sa zbirkom priča Nade Iveljić, autorice koja se svojim bogatim opusom od preko četrdeset knjiga ubraja među najplodnije hrvatske dječje pisce. Šestinski kišobran (1972) sastoji se od dvadeset i šest priča ${ }^{11}$ koje će se u nastavku s Pričama iz davnine usporediti na strukturnoj, epistemološkoj i ontološkoj razini.

Bajke Ivane Brlić-Mažuranić nadahnute su ,usmenopučkim izrazom“(Hranjec 2004: 62), a bajkovitu strukturu pojačavaju inicijalne i epiloške formule koje su svojstvene narodnoj bajci. Ovakve se formule pojavljuju u izvornom ili u nešto izmijenjenom obliku u svim Pričama iz davnine pa tako bajka „Sunce djever i Neva Nevičica“ započinje s „Tako bili mlinar i mlinarica...“ (2002: 9), ${ }^{12}$ a završava s „Tako naredili, tako uzvali, a što ono bijahu svatovi i što se pojavilo po pustoj banovini, toga nema za sto godina ni u devet carevina“ (22). Iako je kraj ove bajke svojevrstan odmak od klasične epiloške formule Živjeli su još dugo u sreći..., ovdje se sugerira sretan kraj. Od narodne bajke Ivana Brlić-Mažuranić ne nasljeđuje kompoziciju priče, ,[jer] narodna bajka pokazuje veliku disciplinu i poštovanje tradicije (...), [a] u njoj su nezamislive onakve razigrane slike koje nas u Pričama iz davnine najviše zanose“" (Bošković-Stulli 1970: 177). Struktura je bajki u Pričama iz davnine dvojaka. Može biti zgusnuta (kao primjerice u „Šumi Striborovoj“) ili razvedena (kao primjerice u bajci „Kako je Potjeh tražio istinu“) (Hranjec 2004: 41).

Sličnost s Pričama iz davnine uočljiva je u zbirci Šestinski kišobran jer ova zbirka obiluje bajkovitim motivima koje autorica posuđuje iz narodne bajke. Međutim, Nada Iveljić ih preoblikuje na moderan način udaljavajući se pritom od umjetničke bajke kakvu piše Ivana Brlić-Mažuranić i približavajući se fantastici.

Inicijalne i epiloške formule, koje bi trebale činiti glavnu strukturnu vezu s narodnom bajkom, u pričama iz zbirke Šestinski kišobran pojavljuju se u krnjem obliku. U uvodu su vrijeme ili mjesto zbivanja točno određeni. Primjerice, u priči „Strašilo na slici“ na početku prve priče stoji rečenica: „Nad bačko selo Tavankut spustila se noć“ (Iveljić 1996: 5), a u priči „Glinenko“: „Živio jednom čovjek po

${ }^{11}$ Priče iz Šestinskoga kišobrana govore o strašilu („Strašilo na slici“), glinenom čovječuljku (,Glinenko“), košuljici s narodnim vezom („Košuljica s narodnim vezom“), šestinskom kišobranu („Šestinski kišobran“), kipu Ribara i zmije na Jezuitskom trgu (,Zmija brončanog ribara“), čipki (,Sestre čipkarice“), peteroščiću Šušu (,Šuš'“), opancima („,Opanci-rastanci“), čovječuljku od tijesta („Pec Ivo, čovječuljak od tijesta“), gromu („Grom, loši strijelac“), stricu Opečiću („Stric Opečić“), licitarskom srcu („Priča o malom licitarskom srcu“), Kazivačici Matiji („Matija, kazivačica“), vrču (,Bilikum - veseli kum“), klopotecu (,Klopotec“), morskoj medvjedici („Morska medvjedica“), mogutu („Mogut"), tkalji Mari („Najljepši san tkalje Mare“), vodenjaku („Vodenjačić iz Krke“), nijemom pčelaru („Priča o nijemom pčelaru“), vili Koprivici („Vila Koprivica“), kožuščiću (,Kožuščićc), štenetu (,Tri puta prodano štene“), sovi („Kraljica noći“), gavranu s dva bijela pera (,Gavran s dva bijela pera“) i kapljici s Plitvica („Kapljica s Plitivica“).

${ }^{12}$ Priče iz davnine citiraju se prema zagrebačkome izdanju iz 2002., a Šestinski kišobran prema varaždinskome izdanju iz 1996. godine. 
imenu Lojzek, kojemu nitko nije znao godine. Bavio se lončarstvom. Izrađujući od gline svoje vrčiće i lončiće proputovao je, kako je sam tvrdio, pola svijeta; to pola svijeta bilo je Hrvatsko Zagorje“ (12). Ovakvi uvodi ne odgovaraju tipičnom bajkovitom početku jer nas i prvi i drugi (iako je drugi sličniji tipično bajkovitoj inicijalnoj formuli), upućuju na određeno mjesto zbivanja. Iako se u priči “Opancirastanci“, po inicijalnoj formuli: „Bili tako jednom jedni opanci“, doima da je riječ o narodnoj bajci, mjesto se radnje izriče već sljedećom rečenicom: „Pojavili su se u Šestinama, najljupkijem selu na svijetu, koje počiva na obroncima gore Medvednice...“ (62). Struktura epiloških formula priča iz navedene zbirke čini još veći odmak od narodne bajke jer autorica u nekim svojim pričama pokušava smrt prikazati kao sretan kraj. Primjerice, priču „Najljepši san tkalje Mare“ završava riječima: „Za takvim životom nije mogla doći teška, bolna smrt, već nestajanje, meko poput pamuka i bijelo poput runa mljetskih ovaca koje je poznato po svilenkastom sjaju“ (140). Tipična kompozicija narodne bajke ovdje je također izostala, ali nije riječ niti o kompoziciji tipičnoga fantastičnoga proznoga teksta jer svaka od ovih fantastičnih priča opisuje samo po jedan fantastični događaj.

Ako razlike između inicijalnih formula u zbirkama Priče iz davnine i Šestinski kišobran sagledamo kroz leću epistemologije, onda bajke Ivane Brlić-Mažuranić upućuju na nepouzdanost, kako je i tipično za bajku, a moderne bajke Nade Iveljić prostorno su lokalizirane pa se može zaključiti da se ne radi o bajkama. No, obje se autorice u svojim pričama služe i drugim usmenim oblicima, a ne samo narodnom bajkom pa je epistemološki pristup nešto složeniji. U imenima likova iz zbirke Priče iz davnine prepoznajemo slavensku mitologiju (usp. Hranjec 2006: 60), ali ih Ivana Brlić-Mažuranić maštovito preobražava za svoje potrebe. Da bi napisala Priče iz davnine, Ivana Brlić-Mažuranić služila se predajama, a inspiriralo ju je djelo A. Afanasjeva Poetsko gledanje Slavena na prirodu (usp. Bošković-Stulli 1970: 164). Predaja je vrsta priče koja sadrži nadnaravne sadržaje, ali je pouzdana, odnosno ona se, za razliku od bajke, temelji na čitateljevoj vjeri u istinitost njezina sadržaja, a to ju epistemološki približava fantastici. Nadnaravni sadržaji u usmenoj prozi zajednički su i bajkama i predajama, ali se oni međusobno značajno razlikuju. Tako i Bošković-Stulli upozorava: „Radi distinkcije nadnaravnih pojava, bajkama bi bliže odgovaralo obilježje čudesnoga, a predajama obilježje fantastike“ (174). Unatoč tomu što Ivana Brlić-Mažuranić ugrađuje predaje u Priče iz davnine, kredibilitet im ruši činjenica da je iz početaka i završetaka jasno da je riječ o bajkovitom sveprostoru.

Nada Iveljić, jednako kao i njezina prethodnica, u svoje priče interpolira predaje i pučka vjerovanja iz hrvatske baštine, ali ima drukčiji pristup. Za razliku od Ivane Brlić-Mažuranić, ona predaje interpolira u zemljopisno provjerljiv prostor, 
odnosno u svojim ih pričama polaže u mjesta u Hrvatskoj u kojima su nastale. Kada iznese sve povijesne činjenice, onda priču najčešće završava tako da čitatelju pruža izbor, nudi mu i da ne povjeruje u ispričano jer „bajka to ni ne zahtijeva“ (Iveljić 1996: 145). Ovaj posljednji dio djelomično potkopava pouzdanost, ali unatoč tomu njene priče na epistemološkoj razini imaju odmak u odnosu na one iz zbirke Priče iz davnine.

Zemljopisno provjerljiv prostor, opisan $\mathrm{u}$ modernim pričama iz zbirke Šestinski kišobran, čini primarni (realistični) svijet. Opreku tome svijetu predstavlja sekundarni (fantastični) svijet, a između njih su, za razliku od narodne bajke, jasno vidljive granice. $U$ ovim pričama postoje dva tipa granica. Prvi tip čine granice koje se otkrivaju mogućnošću prolaza u sekundarni svijet, a drugi tip čine nevidljive granice koje postaju očite čuđenjem stvarnih likova kada se pojavi neki fantastični lik ili predmet koji očito ne pripada primarnomu svijetu. Primjerice, u bajci „Glinenko“ Nada Iveljić spominje sekundarni svijet: „Vjerovalo se da [Glinenko] kroz dug i uzak hodnik pod zemljom odvodi starca u svoje carstvo. Ondje postoji čudesna cvjetna dolina, u kojoj obojica prezime“ (14-15). Ovdje je sekundarni svijet (čudesna cvjetna dolina) odvojen prolazom, odnosno dugim i uskim hodnikom. U bajci „Šuš“ u primarnom se svijetu pojavljuje fantastično biće Šuš koje se sprijateljuje s dječakom Mladenom. Dolaskom bića iz bajke u primarni svijet dolazi do urušavanja ontoloških granica između primarnoga i sekundarnoga svijeta, a isto se događa i u bajci „Vodenjačić iz Krke“, kada se vodenjak imenom Suhi, koji inače živi u rijeci (sekundarni svijet), sprijatelji s djecom iz primarnoga svijeta.

Radnja niti jedne od bajki iz zbirke Priče iz davnine nije ni povijesno niti zemljopisno lokalizirana. Točnije, smještena je u sekundarne svjetove u kojima realistično i fantastično supostoje tako da to nikoga ne iznenađuje. Odmak od svijeta narodne bajke i približavanje umjetničkoj vidljiv je u izboru likova koji mogu biti stvarni, nestvarni i životinje, a isto tako, osim izrazito dobrih i izrazito zlih likova, autorica uvodi i kolebljivce (usp. Hranjec 2004: 61). Primjerice, u „Šumi Striborovoj“ uz crno-bijelu karakterizaciju likova izdvajamo sina koji je naivan, lakomislen i povodljiv, odnosno slabić koji se najprije priklanja jačemu (zlu), da bi se na kraju pokajao zbog svojih postupaka te ipak pristupio strani dobra.

\section{Zaključna razmatranja}

Kao kompleksni i dinamični entiteti, književne vrste i žanrovi se nikada nisu mogli oštro razgraničiti pa spoznaje o prelaženju, a ponekad čak i narušavanju njihovih granica nisu novost. Bajka i fantastika međusobno se prožimaju pa su se u literaturi često poistovjećivale. Njihovim uspoređivanjem, uz primjenu teorijskih 
zaključaka Dietera Petzolda koji upućuju k ontološkome pristupu književnosti, vidljivo je da uz velike sličnosti između bajke i fantastike postoje i velike razlike, pa je tako bajku i fantastiku moguće razlikovati na strukturnoj, epistemološkoj i ontološkoj razini.

Najjednostavniju, strukturnu razliku između navedenih zbirki, čini drukčija kompozicija priče, izostanak tipičnih bajkovitih inicijalnih i epiloških formula, kao i izostanak bajkovitosti u pripovijedanju Nade Iveljić.

Složenija, epistemološka razlika ovdje je vidljiva u načinu interpolacije tradicionalnih sastavnica preuzetih iz narodne bajke. Iako obje autorice u svoje pripovijedi ugrađuju podlogu usmene književnosti, Nada Iveljić, za razliku od Ivane Brlić-Mažuranić, interpolira predaje u provjerljiv prostor, a samim time „priča proizlazi iz potvrđenosti“ (Biti 1981: 122).

Najsloženija, ontološka razlika između zbirki Priče iz davnine i Šestinski kišobran, odnosi se na konstituiranost fikcionalnih svjetova. Ivana Brlić-Mažuranić kroji sekundarni svijet koji se sastoji od različitoga omjera fantastičnih i realističnih elemenata između kojih nema vidljivih granica. U pričama Nade Iveljić granice između fantastičnoga i realističnoga postoje te je moguće govoriti o dvama svjetovima (o primarnome, odnosno realističnome i o sekundarnome, odnosno fantastičnome) koji postoje usporedno, a između njih postoje granice.

Iako je Nada Iveljić tek djelomično preuzela strukturu narodne bajke, ona na njezinim temeljima ipak gradi i veliki odmak. Suprotno zbirci Priče iz davnine, u pričama Nade Iveljić navedena su precizna prostorna određenja koja su inače u pravilu veoma rijetka i „pojavljuju se mahom u suvremenijim primjerima“ (Lihačov 1978: 62). Upravo takva precizna prostorna određenja priča iz zbirke Šestinski kišobran udaljavaju ih od bajke i približavaju fantastičnoj priči. Međutim, kao što ističe Hranjec, „u vođenju radnje, (...) u novim, začudnim likovima i njihovim postupcima, u nedogađanju (s obzirom na očekujući slijed), [odnosno] u igri elementima strukture leži novost, nova bajkovitost" (2004: 54). Očito je da su poveznice s bajkom dovoljno jake da bi se za takve priče nazivi moderna bajka i fantastična priča mogli koristiti kao sinonimi. Fantastika uključuje i modernu bajku, odnosno, moderna bajka takva je pripovijed koja se kao vrsta približava fantastici, i tako postaje hibridni žanr, koji istodobno pripada i bajki kao vrsti i fantastici kao skupini žanrova. S druge strane, zbirka Priče iz davnine može se kategorizirati kao zbirka umjetničkih bajki. 


\section{Popis literature}

\section{Primarna literatura}

Brlić-Mažuranić, Ivana. 1916/2002. Priče iz davnine. Zagreb: Školska knjiga.

Iveljić, Nada. 1972/1996. Šestinski kišobran. Varaždin: Katarina Zrinski.

\section{Sekundarna literatura}

Anić, Vladimir. 2003. Veliki rječnik hrvatskoga jezika. Zagreb: Novi Liber.

Bahtin, Mihail. 1937/1989. „Oblici vremena i hronotopa u romanu.“ U O romanu, 193-276. Beograd: Nolit.

Bahtin, Mihail. 1941/1989. „Ep i roman.“ U O romanu, 435-474. Beograd: Nolit.

Biti, Vladimir. 1981. Bajka i predaja: povijest i pripovijedanje. Zagreb: Sveučilišna naklada Liber.

Bošković-Stulli, Maja. 1970. „Priče iz davnine i usmena književnost.“ U Ivana BrlićMažuranić: zbornik radova, ur. Dubravko Jelačić i dr., 163-182. Zagreb: Mladost.

Bošković-Stulli, Maja. 1991. Pjesme, priče, fantastika. Zagreb: Nakladni zavod Matice hrvatske.

Cipra, Marijan. 2003. Temelji ontologije. Zagreb: Matica hrvatska.

Clute John i John Grant. 1997. The Encyclopedia of Fantasy. London: Orbit.

Crnković, Milan. 1987. Sto lica priče: antologija dječje priče s interpretacijama. Zagreb: Školska knjiga.

Greco, John. 2004. Epistemologija: vodič kroz teorije znanja. Zagreb: Naklada Jesenski i Turk.

Hameršak, Marijana. 2010. „Predodžbe djetinjstva i preobrazbe bajke: primjeri hrvatske dječje književnosti 19. stoljeća.“ Književna smotra 156 (2): 113-123.

Hranjec, Stjepan. 2004. Dječji hrvatski klasici. Zagreb: Školska knjiga.

Hranjec Stjepan. 2004. „Tri modela nove bajkovitosti.“ Umjetnost $i$ dijete 48: 43-56.

Hranjec, Stjepan. 2006. Pregled hrvatske dječje književnosti. Zagreb: Školska knjiga.

Jolles, Andre. 2000. Kratki oblici. Zagreb: Matica hrvatska.

Kravar, Zoran. 2010. Kad je svijet bio mlad: visoka fantastika i doktrinirani antimodernizam. Zagreb: Mentor d. o. o.

Lihačov, Dmitrij Sergejevič. 1978. „Zatvoreno vreme skaske.“U Narodna bajka u modernoj književnosti, ur. Mirjana Drndarski, 62-68. Beograd: Nolit.

Mendlesohn, Farah. 2008. Rhetoric of Fantasy. Middletown: WUP.

Nikolajeva, Maria. 2003. „Fairy tales and Fantasy: From Arhaic to Postmodern.“ Marvels and Tales 17 (1): 138-156.

Pavičić, Jurica. 1996. „Neka pitanja fantastične književnosti.“ Mogućnosti: književnost. Umjetnost. Kulturni problemi 4-6: 133-147.

Peleš, Gajo. 1999. Tumačenje romana. Zagreb: ArTresor.

Petzold, Dieter. 1986. „Fantasy Fiction and Related Genres.“ Modern Fiction Studies 32 (1): 11-21.

Pintarić, Ana. 2008. Umjetničke bajke: teorija, pregled, interpretacija. Osijek: Filozofski fakultet.

Ranke, Kurt. 1978. Die Welt der einfachen Formen. Berlin-New York: Walter de Gruyter.

Solar, Milivoj. 2006. Rječnik književnoga nazivlja. Zagreb: Golden marketing - Tehnička knjiga.

Suvin, Darko. 2001. „Promišljanje o smislu 'fantastike' ili fantastične proze.“ Književna smotra: časopis za svjetsku književnost 33, br. 119 : 47-67.

Težak, Dubravka. 1991. Hrvatska poratna dječja priča. Zagreb: Školska knjiga. 
Težak, Dubravka i Stjepko Težak. 1997. Interpretacija bajke. Zagreb: DiVič.

Tolkien, John Ronald Reuel. 1966. „On Fairy Tales“. U The Tolkien Reader, 29-121. New York: Ballantine books.

Todorov, Tzvetan. 1987. Uvod u fantastičnu književnost. Beograd: Nolit.

Zima, Dubravka. 1997. „Fantastika u suvremenoj hrvatskoj dječjoj prozi.“ U Odrastanje u zrcalu suvremene književnosti za djecu i mladež, ur. Ranka Javor, 40-51. Zagreb: Knjižnice grada Zagreba.

\section{Kristina Giacometti}

Nova Rača Elementary School

Grundschule Nova Rača

\section{From the Marvellous to the Fantastic: Dimensions of the Fictional Worlds of Ivana Brlić-Mažuranić and Nada Iveljić}

By using inspirational polemics on the relationship, and the connection, between the fairy tale and the younger form of fantasy, the author compares and analyzes two fairy tale collections: Priče iz davnine (Croatian Tales of Long Ago) by Ivana Brlić-Mažuranić and Šestinski kišobran [Šestine Umbrella] by Nada Iveljić. While Croatian Tales of Long Ago is considered to be a literary fairy tale collection, Šestine Umbrella is a collection of modern fairy tales/fantasy stories. The author specifies the typology of fictional worlds in the two works through the epistemological, ontological, and structural differences between fairy tales and fantasy literature, two genres often compared and sometimes even identified as one in critical works. Based on previous theoretical insights, literary analysis is performed to show that the fictional worlds in Šestine Umbrella digress from the worlds of Ivana BrlićMažuranić's fairy tale through epistemological, ontological and structural differences, and thereby evolve into fantasy.

Keywords: fairy tale, fantasy, epistemological differences, ontological differences, ontological similarities, structural differences

\section{Vom Wundersamen zum Fantastischen: Die Dimensionen der Welten von Ivana Brlić-Mažuranić und Nada Iveljić}

Anknüpfend an die Diskussionen über die Zusammenhänge zwischen Märchen und der jüngeren Erzählform der Phantastik, werden im Beitrag einzelne Texte aus der Sammlung Priče iz davnine (Geschichten aus Urväterzeiten) von Ivana Brlić-Mažuranić, die man üblicherweise zu den Kunstmärchen zuordnet, mit den modernen Märchen bzw. phantastischen Erzählungen von Nada Iveljić aus ihrer Sammlung Šestinski kišobran [Šestiner Regenschirm] verglichen. Die Typologie und der Charakter der fiktionalen Welten aus diesen zwei Sammlungen werden anhand der epistemologischen, ontologischen und strukturellen Unterschiede zwischen Märchen und Phantastik bestimmt, jenen zwei Erzählformen, die in der Literaturwissenschaft zumeist verglichen, manchmal jedoch auch gleichgestellt werden. Die im Beitrag vorgenommene literaturtheoretische Analyse basiert auf den bisherigen theoretischen Forschungsergebnissen und zeigt auf, dass sich die in der Sammlung Šestinski kišobran enthaltenen Welten in ihrer ontologischen, epistemologischen und strukturellen Dimension von den Märchen entfernen und zu phantastischen Geschichten werden.

Schlüsselwörter: Märchen, phantastische Geschichte, epistemologische Unterschiede, ontologische Unterschiede, ontologische Ähnlichkeiten, Strukturunterschiede 